\title{
Bacterial dynamics in ballast water during trans-oceanic voyages of bulk carriers: environmental controls
}

\author{
Jennica M. Seiden*, Candice J. Way, Richard B. Rivkin \\ Ocean Sciences Center, Memorial University of Newfoundland and Labrador, St. John's, Newfoundland A1C 5S7, Canada
}

\begin{abstract}
Bacterial abundance, population dynamics, and related environmental parameters were determined in ballast water during 2 trans-Pacific voyages from Japan to the west coast of Canada and 2 trans-Atlantic voyages from the Netherlands to the east coast of Canada. Water samples were collected from ballast tanks that either underwent mid-ocean exchange (MOE) or were unexchanged (control). Bacterial abundances in the MOE and control tanks were not significantly different at the end of the voyage. Moreover, abundances were not lower immediately after compared with immediately before MOE, suggesting that MOE alone is not effective in reducing ballast water bacterial abundances. Results of this study suggest that the duration of the voyage plays a critical role in determining the potential bacterial propagule pressure. Although the bacterial growth dynamics were complex, we found robust relationships and a highly significant predictive relationship between bacterial abundance and both temperature and dissolved oxygen concentrations of the ballast water $(\mathrm{p}<$ 0.001). This robust relationship allows the prediction of potential bacterial propagule pressure from environmental characteristics within the ballast tanks.
\end{abstract}

KEY WORDS: Atlantic Ocean · Ballast water $\cdot$ Heterotrophic bacteria $\cdot$ Invasive species $\cdot$ Oxygen Pacific Ocean $\cdot$ Predictive model $\cdot$ Mid-ocean exchange $\cdot$ Temperature

\section{INTRODUCTION}

Ballast water, which is taken on-board and stored in tanks to enhance the ship's stability and maneuverability during transit, is a vector of ship-mediated transport and introduction of aquatic invasive organisms (IMO 2008). These aquatic invaders have the potential to alter, or already have altered, the ecology, biodiversity, and functioning of the aquatic ecosystem (DFO [Fisheries and Oceans Canada] 2007, Ruiz \& Reid 2007, Rilov \& Crooks 2009). Although natural dispersal mechanisms, such as ocean currents, enable marine organisms to expand their geographic range, large ocean-going ships are now a mechanism for widespread rapid species dispersal at ocean basin to global scales. Ships transport $\sim 80 \%$ of the world's commodities (Carlton 1999), and this has changed the patterns and increased the rates of invasions and introduction of organisms into environments where they would nor- mally not be found (MacIsaac et al. 2002, Joachimsthal et al. 2004).

Approximately $3 \times 10^{9}$ to $5 \times 10^{9} \mathrm{~m}^{3}$ of ballast water is annually transported and everyday 7000 to 10000 different marine species are transported in ballast water (IMO 2008). Although the abundance and species diversity generally declines as ballast water ages, some organisms have the ability to endure the conditions in the ballast tanks (Ruiz et al. 2000, Drake et al. 2007, Gregg \& Hallegraeff 2007). At present, midocean exchange (MOE) of ballast water is the main method used to control the introduction of aquatic invasive species (IMO 2008). International Maritime Organization guidelines (IMO 2008) require ships to exchange ballast water at least 200 nautical miles offshore at ocean depths greater than 2000 m (Transport Canada 2007), and when conducted in compliance with these guidelines, MOE can reduce the initial concentration of planktonic organisms by 80 to $95 \%$ (Ruiz 
\& Reid 2007). However, the ballast tanks typically retain low abundances of coastal organisms in residual water in the tanks, and euryhaline organisms may be able to survive the dilution with high salinity water (Wonham et al. 2001, Taylor et al. 2007, Transport Canada 2007).

Most studies on ballast-mediated introductions of invasive organisms have generally been on eukaryotes, for example invertebrates, such as the zebra mussel Dreissena polymorpha (Hebert et al. 1989), or protozoa, such as dinoflagellate vegetative cells and cysts (Hallegraeff 1998, Gregg \& Hallegraeff 2007). Very little is known about the factors regulating microbial dynamics in ballast water during transit between ports. Recent studies, however, have shown that heterotrophic prokaryotes and viruses numerically dominate ballast water biota (Rigby et al. 1999, Ruiz et al. 2000, Drake et al. 2002, Burkholder et al. 2007, Ma et al. 2009, Seiden et al. 2010, Sun et al. 2010), and some of these microbes may be pathogenic. Bacteria are small (typically 0.2 to $1 \mu \mathrm{m}$ ), ubiquitous and abundant, and are capable of enduring the conditions in ballast tanks as spores or other resting stages (Ruiz et al. 2000, Gregg \& Hallegraeff 2007), and thus possess the characteristics that favour their successful introduction into new environments. Most ballast water studies have examined microbial abundances at the deballasting location, and relatively few have monitored the changes that occurred in transit (Olenin et al. 2000, Gollasch et al. 2000a,b, Drake et al. 2002, Mimura et al. 2005, Seiden et al. 2010, Tomaru et al. 2010).

There are surprisingly few studies characterizing bacterial abundance and dynamics in ballast water during transit from the uptake to deballasting (Drake et al. 2002, Seiden et al. 2010, Tomaru et al. 2010). To assess the risk associated with transporting microorganisms in ballast water, it is essential to understand their dynamics (i.e. changes in abundances and/or composition) that occur during transit. Three fundamental questions that remain largely unexplored are: (1) What changes occur to bacteria populations present in ballast water during transit from one port to another? (2) What physical factors control these changes? (3) What are the effects of MOE on the ballast water bacterial community deballasted into coastal waters? Here, we report on a comprehensive study that assessed the temporal pattern of change in heterotrophic bacteria in relation to environmental factors in ballast water during 2 trans-Pacific and 2 transAtlantic voyages. Although the bacterial growth dynamics were complex among the 4 voyages, we found robust relationships and a very significant predictive relationship between bacterial abundance and both temperature and dissolved oxygen concentration of the ballast water.

\section{MATERIALS AND METHODS}

In the North Pacific Ocean, studies were conducted onboard the MV 'Skaugran' (bulk carrier: $182.5 \mathrm{~m}$ long; 41900 gross tons) from 26 July to 16 August 2007 (trans-Pacific 1; TP1) and from 18 September to 10 October 2007 (TP2). Ballast water was sampled daily for physicochemical parameters and every third day for bacterial abundances, as well as immediately before and after MOE, between Hakata, Japan, and New Westminster, British Columbia, Canada (Fig. 1A). Although both TP voyages departed from Hakata, Japan, during TP1, ballast water was taken onboard near Inchon, South Korea, and this is considered the source port. In the North Atlantic Ocean, studies were conducted onboard the MV 'Eva N' (bulk carrier; $305 \mathrm{~m}$ long; 107512 gross tons) from 15 to 24 October (trans-Atlantic 1; TA1) and 16 to 23 November 2008 (TA2). Ballast water was sampled daily (weather permitting) for physicochemical parameters and bacterial abundances between Rotterdam, The Netherlands, and Sept-Iles, Quebec, Canada (Fig. 1B).

Ballast and port water sampling. For the TP voyages, 4 ballast tanks (top side upper wing tanks) were sampled; 2 of the tanks underwent exchange (MOE) and 2 tanks remained unexchanged (control). The paired (MOE vs. control) tanks allowed the efficacy of MOE in reducing bacterial numbers to be assessed. MOE was on Day 14 and 15 during TP1 and TP2, respectively, after samples had been taken. The ships' routes and locations of MOE are shown in Fig. 1A.

For the TA voyages, 4 ballast tanks (top side upper wing tanks) were sampled; all the tanks for these voyages underwent $\mathrm{MOE}$, albeit at different times. The first and second set of MOE tanks that were exchanged are designated MOE1 and MOE2, respectively. For TA1, MOE1 began on Day 2 and finished on Day 3, whereas MOE2 was on Day 6. For TA2, MOE1 was on Day 3 and MOE2 was on Day 4. In all cases, MOE took place after daily samples had been taken. The ships' routes and locations of MOE are shown in Fig. 1B.

Temperature, dissolved oxygen concentrations (mg $\mathrm{l}^{-1}$ ), and salinity (psu) of the ballast tank water was measured daily using a handheld YSI Model 85 meter at 3 depths of the ballast tanks. For the TP voyages, water was sampled from the surface $(0 \mathrm{~m})$, middle $(2 \mathrm{~m})$, and mid-bottom $(4 \mathrm{~m})$. For the TA voyages, samples were taken from the surface, middle and bottom at 0,10 and $20 \mathrm{~m}$ for TA1, and 1,5 and $10 \mathrm{~m}$ for TA2. Since there were no depth-related differences for these variables, we computed ballast tank average temperature, dissolved oxygen concentrations, and salinity from the 3 depths. At 1 to $3 \mathrm{~d}$ intervals, water samples were collected using a 51 Niskin bottle (de- 
Fig. 1. Ships' routes of (A) MV 'Skaugran' on trans-Pacific voyages TP1 (-) and TP2 (-----), and (B) MV 'Eva N' on transAtlantic voyages TA1 (-) and TA2 (-----). Sites of mid-ocean exchange (MOE) are shown as follows: (A) (較) TP1 on Day 14 at $44^{\circ} 30.501^{\prime} \mathrm{N}, 171^{\circ} 16.837^{\prime} \mathrm{E}_{i}(\star)$ TP2 on Day 15 at $46^{\circ} 34.342^{\prime} \mathrm{N}, 177^{\circ} 25.578^{\prime} \mathrm{W}$. (B) TA1 (次) MOE1 tanks on Days 2 to 3 at approximately $50^{\circ} 12.27^{\prime} \mathrm{N}, \quad 1^{\circ} 06.59^{\prime} \mathrm{W}$ and ( $\star$ ) MOE2 tanks on Day 6 at approximately $51^{\circ} 12.97^{\prime} \mathrm{N}, 38^{\circ} 00.89^{\prime} \mathrm{W}$; TA2 (引) MOE1 tanks on Day 3 at approximately $50^{\circ} 11.39^{\prime} \mathrm{N}, 16^{\circ} 37.80^{\prime} \mathrm{W}$ and (\$) MOE2 tanks on Day 4 at approximately $50^{\circ} 34.90^{\prime} \mathrm{N}, 25^{\circ} 33.72^{\prime} \mathrm{W}$

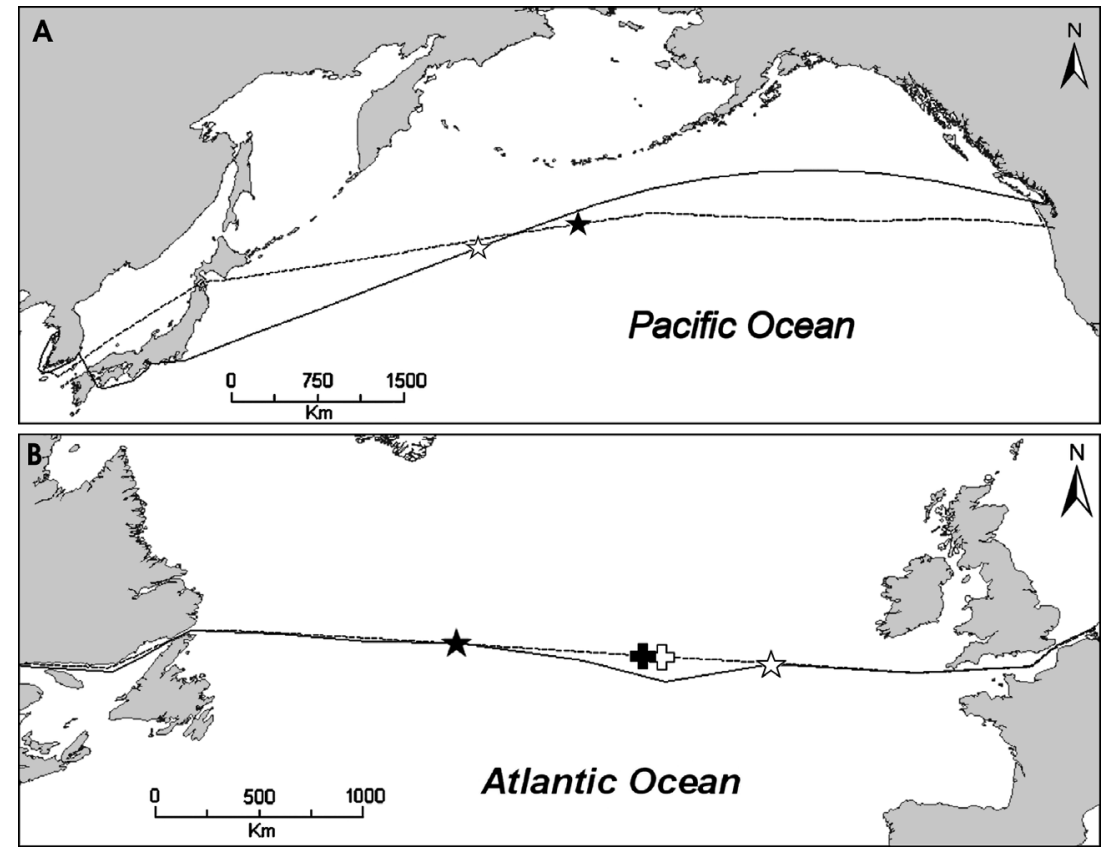

ployed into the ballast tank through a deck hatch or over the side of the ship for port samples) at the same 3 depths as those for physicochemical parameter measurements. Water from each ballast tank was pooled into a 15-1 carboy that was pre-rinsed in $2 \% \mathrm{HCl}$ and distilled water. This integrated ballast water sample was considered to be representative of the water column, and was subsampled for bacterial properties. In addition, ambient sea water temperatures were monitored daily (obtained from the ship's log).

In the North Pacific, samples were collected from the source ports (TP1: Inchon, South Korea at 0, 4 and 8 m; TP2: Osaka Harbour, Japan at 0, 2 and $4 \mathrm{~m}$ ), and from the destination port (at 0,2 and $4 \mathrm{~m}$ ). In the North Atlantic, samples were collected from source (at 1, 4 and $7.5 \mathrm{~m}$ ) and destination (at 1 and $8 \mathrm{~m}$ ) ports during TA2 and from the destination port only (at $0 \mathrm{~m}$ ) during TA1. Environmental parameters of the port water were measured at the same depths as those of the samples and as described above.

Analytical methods. Samples for bacterial enumeration were fixed with $\sim 2 \%$ (final concentration) formaldehyde and stored in the dark at $4{ }^{\circ} \mathrm{C}$ until analysis, within $3 \mathrm{~d}$ of their receipt in the laboratory. Samples were prepared by filtering $10 \mathrm{ml}$ of preserved ballast and port water onto $25 \mathrm{~mm}$ diameter, $0.22 \mu \mathrm{m}$ black polycarbonate filters (GE Osmonics), staining with $200 \mu \mathrm{l}$ of 4',6-diamido-2-phenylindole (DAPI; $5 \mu \mathrm{g}$ $\mathrm{ml}^{-1}$ ) that excites at $359 \mathrm{~nm}$ and emits at $461 \mathrm{~nm}$, and mounting on slides in Cargille Type A immersion oil (Porter \& Feig 1980). Slides were stored at $-20^{\circ} \mathrm{C}$ until counting. Epifluorescence direct counts were made using an Olympus BH2-RFCA equipped with a wide band blue filter (120x oil immersion lens; total magnification $1250 \times$ ). For each filter, bacteria were counted in 10 to 20 fields of view and at least 600 cells per filter were counted. The average coefficients of variation (CV) of bacterial counting were $17 \%$ and $16 \%$ for TP1 and TP2, respectively; and $20 \%$ and $16 \%$ for TA 1 and TA2, respectively.

The rates of bacterial growth and loss for each tank and voyage were computed from the slope of the regression of the relationship between time (d) and the natural logarithm of bacterial abundance. Similarly, rates of change in dissolved oxygen concentrations were computed from the slope of the regression relationship between time (d) and the dissolved oxygen concentrations.

Cell size and cell morphometrics were determined using image analysis (ImagePro Plus v. 6.2). Images of cells on each filter were captured, stored, and individually examined for a minimum of 1000 cells per filter. The volumes were calculated assuming cells with an aspect ratio $<1.5$ were spheres and cells with an aspect ratio $\geq 1.5$ were cylinders. Cell volumes were converted to cell carbon according to Norland (1993).

Bacterial respiration (BR) was estimated during the positive growth phases of TP1 and TA2. We did not determine respiration during TP2 or TA1 because either there was no net growth or the pattern or duration of positive net growth was not comparable among tanks. Bacterial production (BP) was computed as the product of the net growth rate and the bacterial cell carbon. From estimates of BP and the ballast water temperatures, BR was calculated according to the algorithm of Rivkin \& Legendre (2001) as follows: 


$$
\mathrm{BR}=(\mathrm{BP} / \mathrm{BGE})-\mathrm{BP}
$$

where BGE is the bacteria growth efficiency that is estimated from temperature $(T)$ :

$$
\mathrm{BGE}=0.374-0.0104 T
$$

By combining Eqs. (1) and (2), BR is computed as:

$$
\mathrm{BR}=[\mathrm{BP} /(0.374-0.0104 T)]-\mathrm{BP}
$$

Since observed bacterial growth is net (i.e. including mortality), production and respiration are likely underestimated.

Data analyses and model development. The relationships between bacterial abundance and the environmental parameters temperature, dissolved oxygen concentrations and salinity of the ballast tanks was assessed using bivariate and multiple linear regression analyses. Differences in response variables (bacterial abundance, cell volume, and cell morphometrics) in the MOE and unexchanged tanks, and in port water, were determined using the General Linear Model and 1-way Analysis of Variance (ANOVA). All statistical analyses were conducted using Minitab v. 14.
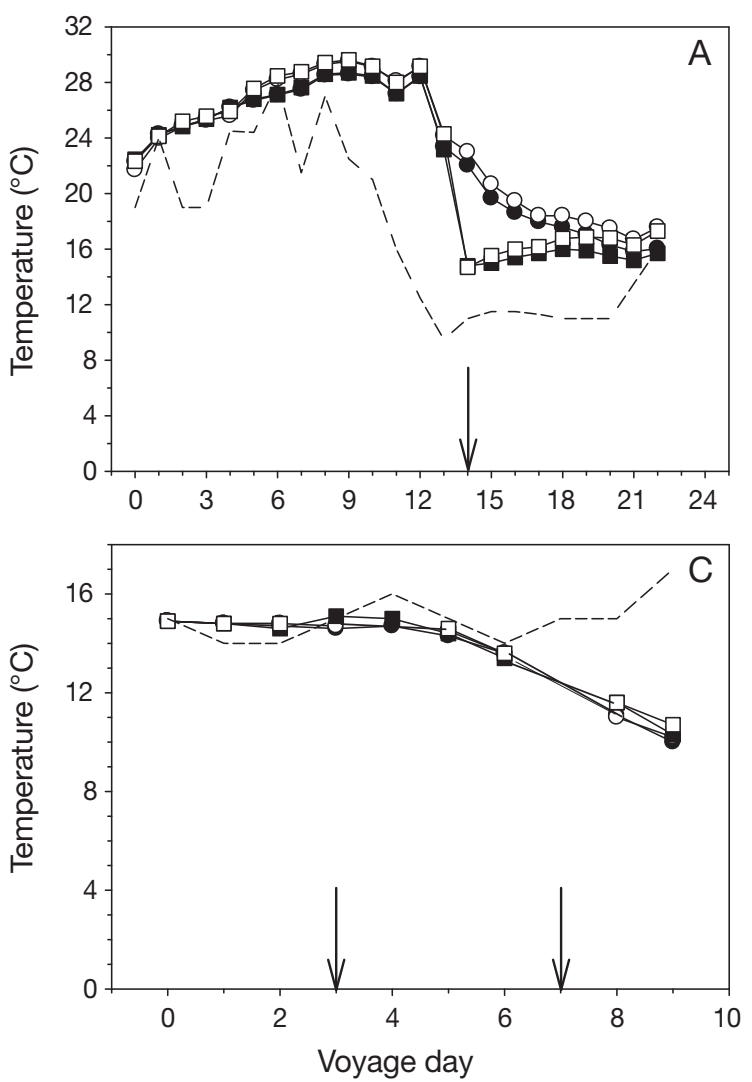

Bacterial abundance was predicted from concurrently measured environmental parameters within the ballast tanks using Model 1 regression. Reduced Major Axis (RMA) Model 2 regression was used to describe the functional relationship between predicted and observed bacterial abundances. Model 2 regression analysis was conducted using R 2.11.1.

\section{RESULTS}

\section{Physicochemical parameters}

Trans-Pacific voyages

During TP1, initial ballast water temperature was sampled while still in port (Day 0) and ranged from 21.7 to $22.5^{\circ} \mathrm{C}$. The temperatures in all ballast tanks followed the same general trend during the voyage (Fig. 2A), increasing to a maximum on Day 9, followed by a slow decline, which was more pronounced in the MOE tanks on Day 14 after exchange, and remaining
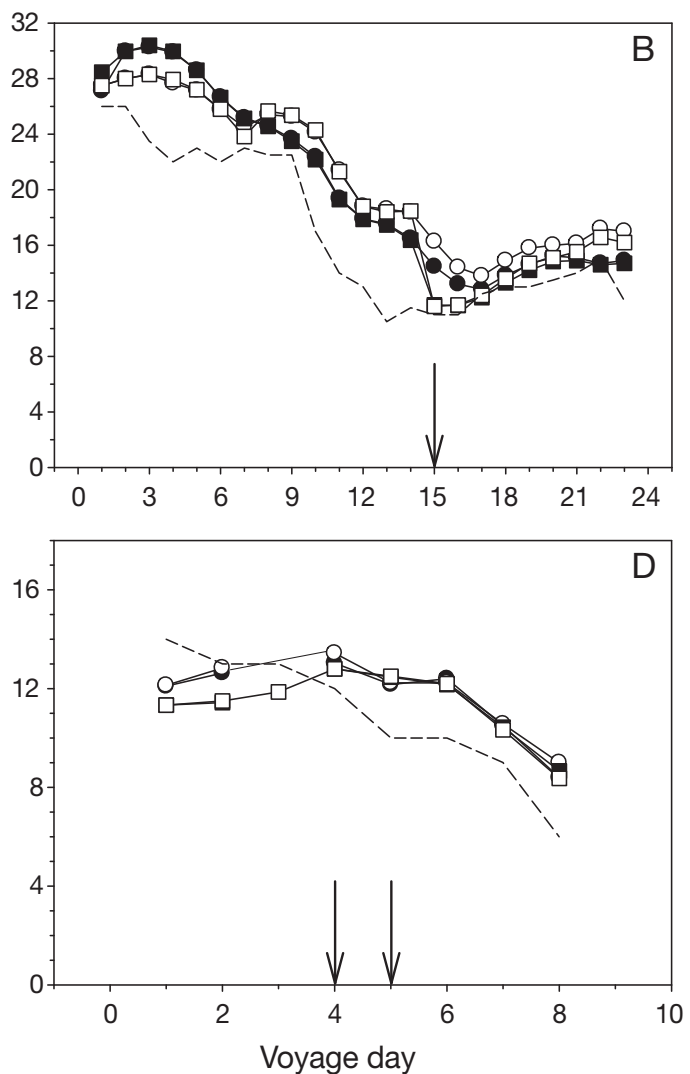

Fig. 2. Temperature of the ballast water, during trans-Pacific (TP) and trans-Atlantic (TA) voyages, in tanks undergoing mid-

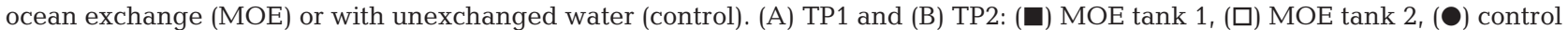

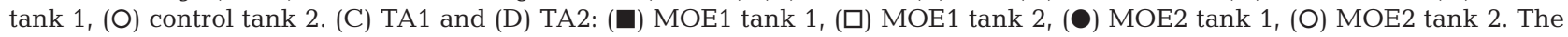
dashed lines show the ambient ocean water temperatures recorded in the ship's daily log. Note the different scales for TP and TA temperatures. Downward arrows indicate the day ballast water was exchanged 

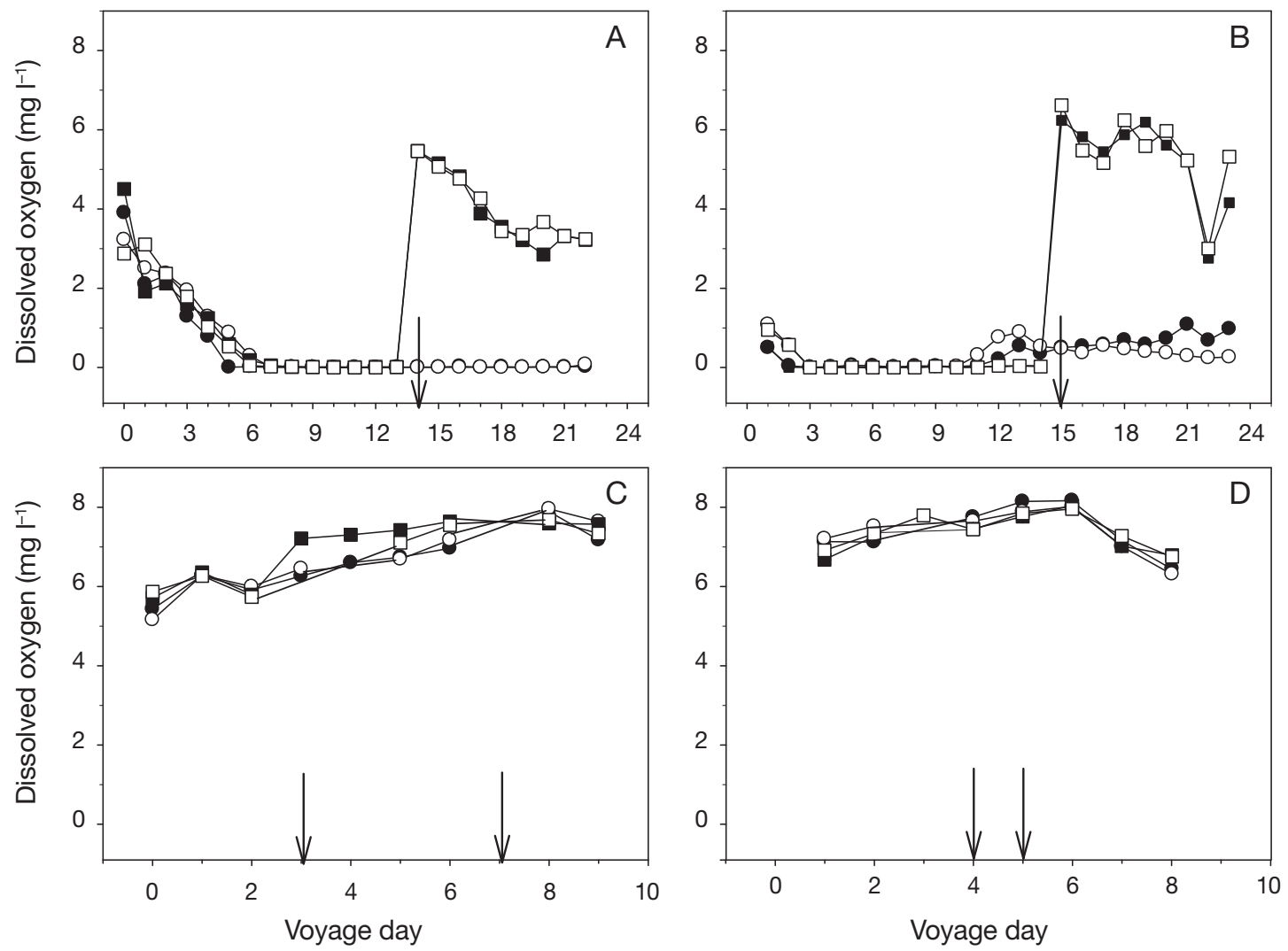

Fig. 3. Dissolved oxygen concentrations of the ballast water, during trans-Pacific (TP) and trans-Atlantic (TA) voyages, in tanks undergoing mid-ocean exchange (MOE) or with unexchanged water (control). (A) TP1, (B) TP2, (C) TA1 and (D) TA2. See Fig. 2 legend for key to symbols. Downward arrows indicate the day ballast water was exchanged

relatively constant afterwards. During TP2, initial ballast water temperature was sampled on the first transit day after departing port (Day 1); temperatures were higher than for TP1 and ranged from 27.1 to $28.5^{\circ} \mathrm{C}$. Temperatures in all tanks followed the same general trend during the voyage, increasing to a maximum on Day 3, followed by a slow decline, which was more pronounced in the MOE tanks on Day 15 after exchange, and remaining relatively constant afterwards (Fig. 2B). The temperature of the ballast tanks during both voyages paralleled the ambient ocean water temperatures with an approximate 2 to 3-day time lag (Fig. 2A,B).

During TP1, dissolved oxygen concentrations in all tanks ranged from 2.9 to $4.5 \mathrm{mg} \mathrm{O}_{2} \mathrm{l}^{-1}$ on Day 0 and declined at an average rate of $\sim 0.56 \mathrm{mg} \mathrm{O}_{2} \mathrm{l}^{-1} \mathrm{~d}^{-1}$ to below detectable levels on Day 6 (Fig. 3A). After Day 6, the ballast water in the control tanks was near-anoxic for the remainder of the voyage. The introduction of oceanic water on Day 14 in the MOE tanks increased the dissolved oxygen concentrations (Fig. 3A) and was followed by a decrease at $\sim 0.31 \mathrm{mg} \mathrm{O}_{2} \mathrm{l}^{-1} \mathrm{~d}^{-1}$. During TP2, the same patterns in dissolved oxygen concentrations were observed except that the initial concentra- tions were lower at the start of the voyage (range 0.5 to $1.1 \mathrm{mg} \mathrm{O}_{2} \mathrm{l}^{-1}$ ) and declined at a rate of $\sim 0.39 \mathrm{mg} \mathrm{O}_{2} \mathrm{l}^{-1}$ $\mathrm{d}^{-1}$ to undetectable levels on Day 3 (Fig. 3B). The ballast water in the control tanks was at or below the level of detection for the remainder of the voyage. In the MOE tanks, the introduction of oceanic water on Day 15 increased dissolved oxygen concentrations and was followed by a decrease at $\sim 0.26 \mathrm{mg} \mathrm{O}_{2} \mathrm{l}^{-1} \mathrm{~d}^{-1}$ (Fig. 3B).

For TP1, salinity ranged from 30.5 to $31.7 \mathrm{psu}$ in the control tanks and 30.5 to $31.6 \mathrm{psu}$ in the MOE tanks prior to exchange and $\sim 32.7$ psu afterwards. For TP2, salinity ranged from 30.7 to $31.8 \mathrm{psu}$ in the control tanks and 28.0 to $31.8 \mathrm{psu}$ in the MOE tanks prior to exchange and $\sim 32.2 \mathrm{psu}$ afterwards (data not shown).

\section{Trans-Atlantic voyages}

During TA1, initial ballast water temperature, sampled while still in port (Day 0), was $14.9^{\circ} \mathrm{C}$ in both MOE1 and MOE2 tanks; temperatures declined throughout the voyage (Fig. 2C). During TA2, initial ballast water temperature, sampled on first transit day (Day 1), was 11.3 and $12.1^{\circ} \mathrm{C}$ in MOE1 and MOE2 
tanks, respectively. In all ballast tanks, temperatures increased until Day 4, and declined thereafter (Fig. 2D). Ballast water temperature was generally similar to ambient ocean water temperatures, except for Days 6 to 10 of TA1, where ballast water temperature declined despite an increase in ocean water temperatures (Fig. 2C,D). The reason for this divergent trend is unclear.

During TA1, dissolved oxygen concentrations ranged from 5.2 to $5.9 \mathrm{mg} \mathrm{O}_{2} \mathrm{l}^{-1}$ at the start of the voyage (Day 0) and increased at $\sim 0.23 \mathrm{mg} \mathrm{O}_{2} \mathrm{l}^{-1} \mathrm{~d}^{-1}$ until Day 8 (Fig. 3C). During TA2, dissolved oxygen concentrations in all tanks ranged from 6.7 to $7.2 \mathrm{mg} \mathrm{O}_{2} \mathrm{l}^{-1}$ at the start of the voyage (Day 1) and increased at $\sim 0.20 \mathrm{mg}$ $\mathrm{O}_{2} \mathrm{l}^{-1} \mathrm{~d}^{-1}$ until Day 6 (Fig. 3D). They decreased thereafter at 0.62 and $0.86 \mathrm{mg} \mathrm{O}_{2} \mathrm{l}^{-1} \mathrm{~d}^{-1}$ in MOE1 and MOE2 tanks, respectively.

For TA1, salinity ranged from 30.2 to 30.4 psu in MOE1 tanks and 29.5 to 30.9 psu in MOE2 tanks prior to exchange and was $\sim 35.2$ and $\sim 33.4 \mathrm{psu}$, respectively, afterwards. For TA2, salinity ranged from 29.4 to $30.2 \mathrm{psu}$ in MOE1 tanks and 30.5 to $32.5 \mathrm{psu}$ in MOE2 tanks prior to exchange and was $\sim 34.5$ and $\sim 34.3 \mathrm{psu}$, respectively, afterwards (data not shown).

\section{Bacterial variables}

Trans-Pacific voyages

During TP1, in both the control and MOE ballast tanks bacterial abundances significantly ( $\mathrm{p}=0.01$ to 0.02) increased between Day 0 and Days 7 (control) and 10 (MOE), and then significantly ( $p=0.02$ to 0.03 ) decreased by Day 22 (Fig. 4A). The end-of-voyage bacterial abundances were not significantly different among the 4 ballast tanks sampled or from the abundance on Day 0 (Table 1). During TP2, control ballast tanks bacterial abundances significantly $(p=0.05)$ decreased between Days 1 and 24 (Fig. 4B, Table 1). In the MOE tanks, despite the transient increase in bacterial abundances between Days 7 and 13, bacterial abundance significantly $(\mathrm{p}=0.02)$ decreased between Days 1 and 24 (Fig. 4B, Table 1). The end-of-voyage bacterial abundances were not significantly different among the 4 tanks sampled; however, unlike TP1, the end-of-voyage bacterial abundances were significantly $(p=0.05$, control; $\mathrm{p}=0.02, \mathrm{MOE}$ ) lower than on Day 1 (Table 1).

The changes in bacterial abundances in the ballast tanks were divided into growth and loss (i.e. net mor-
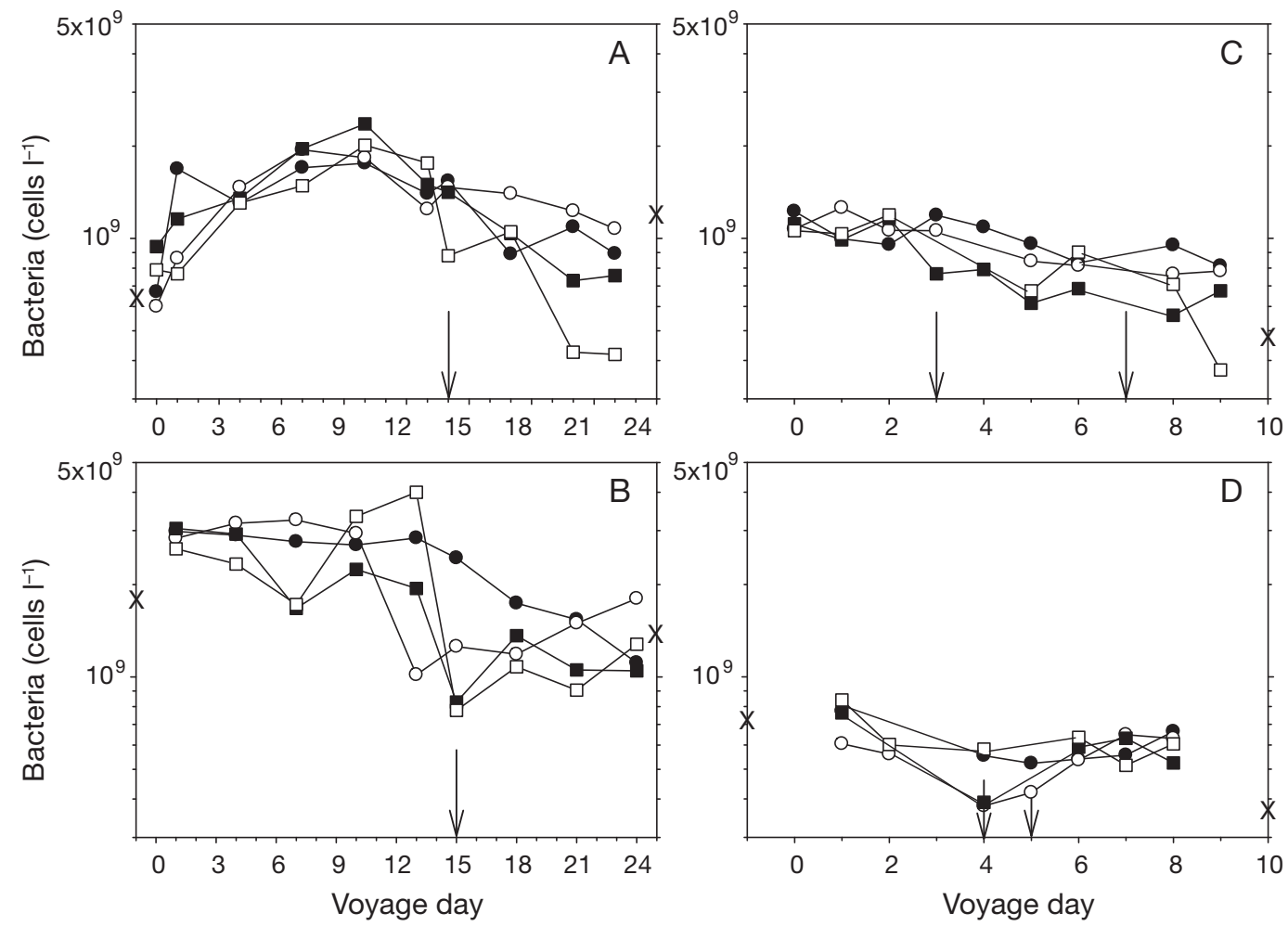

Fig. 4. Bacterial abundance of the ballast water, during trans-Pacific (TP) and trans-Atlantic (TA) voyages, in tanks undergoing mid-ocean exchange (MOE) or with unexchanged water (control). (A) TP1, (B) TP2, (C) TA1 and (D) TA2. See Fig. 2 legend for key to symbols. Downward arrows indicate the day ballast water was exchanged; (X) indicates bacterial abundance in source (left) and receiving port water (right). Note that no source port water samples were collected during TA1 
Table 1. Results of 1-way ANOVA comparing differences in bacterial abundance, bacterial cell volume and percent rod-shaped cells in ballast tanks during 2 trans-Pacific (TP1, TP2) and 2 trans-Atlantic (TA1, TA2) voyages. For TP voyages, comparison is between tanks that underwent mid-ocean exchange (MOE) and those that did not (control); for TA voyages, comparison is between tanks that underwent exchange earlier (MOE1) and later (MOE2). For the TP control tanks, where there was no exchange, the time periods 'before' and 'after exchange' are the same as for the corresponding MOE tanks. Differences between ballast water bacterial abundances with receiving port waters are shown for each tank treatment as well as all 4 tanks combined. Significance at $\mathrm{p} \leq 0.05$ is shown as (NS) no significant difference, $(-)$ significant decrease or (+) significant increase

\begin{tabular}{|c|c|c|c|c|c|c|c|c|}
\hline \multirow{2}{*}{ Voyage } & \multirow{2}{*}{$\begin{array}{c}\text { Ballast tank } \\
\text { treatment } \\
(\mathrm{n}=2)\end{array}$} & \multirow[b]{2}{*}{$\begin{array}{l}\text { Initial vs. } \\
\text { end-of- } \\
\text { voyage }\end{array}$} & \multicolumn{2}{|c|}{ - Bacterial abundance } & \multirow{2}{*}{\multicolumn{2}{|c|}{$\begin{array}{l}\text { End-of-voyage } \\
\text { vs. receiving } \\
\text { port waters }\end{array}$}} & \multirow{2}{*}{$\begin{array}{l}\text { Bacterial cell } \\
\text { volume before } \\
\text { vs. after MOE }\end{array}$} & \multirow{2}{*}{$\begin{array}{l}\% \text { rod-shaped } \\
\text { cells before vs. } \\
\text { after MOE }\end{array}$} \\
\hline & & & $\begin{array}{c}\text { Before } \\
\text { vs. after } \\
\text { MOE }\end{array}$ & $\begin{array}{l}\text { Comparison } \\
\text { among ballast } \\
\text { tanks }\end{array}$ & & & & \\
\hline \multirow[t]{2}{*}{ TP1 } & MOE & NS & NS & \multirow{2}{*}{ NS } & NS & \multirow{2}{*}{ NS } & NS & NS \\
\hline & Control & NS & NS & & NS & & NS & NS \\
\hline \multirow[t]{2}{*}{ TP2 } & MOE & - & NS & \multirow{2}{*}{ NS } & NS & \multirow{2}{*}{ NS } & NS & NS \\
\hline & Control & - & NS & & NS & & NS & NS \\
\hline \multirow[t]{2}{*}{ TA1 } & MOE1 & - & - & \multirow{2}{*}{ NS } & NS & \multirow{2}{*}{ NS } & NS & NS \\
\hline & MOE2 & - & NS & & + & & + & + \\
\hline \multirow[t]{2}{*}{ TA2 } & MOE1 & & NS & \multirow{2}{*}{ NS } & NS & \multirow{2}{*}{+} & + & NS \\
\hline & MOE2 & - & NS & & + & & NS & NS \\
\hline
\end{tabular}

Table 2. Phases of growth (positive net growth) and mortality (negative net growth) and the respective net growth rates of bacteria during trans-Pacific (TP) and trans-Atlantic (TA) voyages. Phases are shown as beginning to end day; at Day 0, the vessel is still in port and Day 1 is the first transit day. For TP voyages, the columns to the left and right compare tanks that underwent midocean exchange (MOE) and those that did not (control); for TA voyages, comparison is between tanks that underwent exchange earlier (MOE1) and later (MOE2). See 'Material and methods' for calculations of rates of growth and mortality

\begin{tabular}{|c|c|c|c|c|c|c|}
\hline Voyage & $\begin{array}{l}\text { Ballast tank } \\
\text { treatment } \\
\text { and number }\end{array}$ & $\begin{array}{l}\text { Phase } \\
\text { (d) }\end{array}$ & $\begin{array}{c}\text { Average net } \\
\text { growth } \\
\text { rate }\left(\mathrm{d}^{-1}\right)\end{array}$ & $\begin{array}{l}\text { Ballast tank } \\
\text { treatment } \\
\text { and number }\end{array}$ & $\begin{array}{l}\text { Phase } \\
\text { (d) }\end{array}$ & $\begin{array}{c}\text { Average net } \\
\text { growth rate } \\
\qquad\left(\mathrm{d}^{-1}\right)\end{array}$ \\
\hline \multirow[t]{2}{*}{ TP1 } & MOE tank 1 & $\begin{array}{r}0-10 \\
10-22\end{array}$ & $\begin{array}{l}+0.09 \\
-0.09\end{array}$ & Control tank 1 & $\begin{array}{l}0-7 \\
7-22\end{array}$ & $\begin{array}{l}+0.13 \\
-0.04\end{array}$ \\
\hline & MOE tank 2 & $\begin{array}{r}0-10 \\
10-22\end{array}$ & $\begin{array}{l}+0.09 \\
-0.13\end{array}$ & Control tank 2 & $\begin{array}{l}0-7 \\
7-22\end{array}$ & $\begin{array}{l}+0.17 \\
-0.04\end{array}$ \\
\hline \multirow[t]{2}{*}{ TP2 } & MOE tank 1 & $1-24$ & -0.05 & Control tank 1 & $1-24$ & -0.04 \\
\hline & MOE tank 2 & $\begin{array}{r}1-13 \\
15-24\end{array}$ & $\begin{array}{l}+0.04 \\
+0.06\end{array}$ & Control tank 2 & $\begin{array}{r}1-10 \\
10-13 \\
13-24\end{array}$ & $\begin{array}{l}+0.003 \\
-0.35 \\
+0.05\end{array}$ \\
\hline \multirow[t]{2}{*}{ TA1 } & MOE1 tank 1 & $0-9$ & -0.06 & MOE2 tank 1 & $0-9$ & -0.05 \\
\hline & MOE1 tank 2 & $0-9$ & -0.12 & MOE2 tank 2 & $0-9$ & -0.04 \\
\hline \multirow[t]{2}{*}{ TA2 } & MOE1 tank 1 & $\begin{array}{l}1-4 \\
4-8\end{array}$ & $\begin{array}{l}-0.22 \\
+0.07\end{array}$ & MOE2 tank 1 & $\begin{array}{l}1-5 \\
5-8\end{array}$ & $\begin{array}{l}-0.10 \\
+0.08\end{array}$ \\
\hline & MOE1 tank 2 & $\begin{array}{l}1-4 \\
4-8\end{array}$ & $\begin{array}{l}-0.12 \\
+0.01\end{array}$ & MOE2 tank 2 & $\begin{array}{l}1-4 \\
4-8\end{array}$ & $\begin{array}{l}-0.16 \\
+0.13\end{array}$ \\
\hline
\end{tabular}

tality) phases (Table 2, Fig. 4). During TP1, the average bacterial growth rate in the control tanks was $\sim 0.15 \mathrm{~d}^{-1}$ during the first $7 \mathrm{~d}$ and averaged $-0.04 \mathrm{~d}^{-1}$ (i.e. net mortality) from Days 7 to 22 (Fig. 4A). The average bacterial growth rate in the MOE tanks was $\sim 0.09 \mathrm{~d}^{-1}$ during the first $10 \mathrm{~d}$ and averaged $-0.11 \mathrm{~d}^{-1}$ from Days 10 to 22 . Bacterial abundances started to decrease on Day 10, 4 days before MOE.

During TP2, the patterns in phases of growth differed among ballast tanks. For control and MOE tanks 1, there was a general decline $\left(-0.04\right.$ and $-0.05 \mathrm{~d}^{-1}$, respectively) between Days 1 and 24 (Fig. 4B, Table 2). For control and MOE tanks 2, the patterns of change in bacterial abundance were complex with periods of net increase and decrease in abundance with an overall pattern of net mortality (Fig. 4B, Table 2).

As a proxy for diversity and community characteristics, we compared the cell morphometrics (cell volumes and \% rod-shaped cells) at the beginning (all samples collected before the date of MOE) and the end 
of the voyage (all samples collected after the date of MOE). There were no significant differences in cell volume or percent of rod-shaped cells at the beginning and end of either voyage (Tables $1 \& 3$ ).

Water samples were also collected from both the source and receiving port waters. For TP1, bacterial abundances in source port and receiving port waters were $6.7 \times 10^{8}$ and $1.3 \times 10^{9}$ cells $^{-1}$, respectively. Abundances were significantly $(p=0.04)$ higher in receiving port waters. For TP2, bacterial abundances in source port and receiving port waters were $1.8 \times 10^{9}$

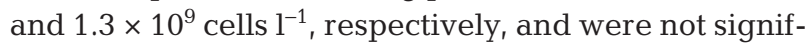
icantly different $(p=0.19)$.

\section{Trans-Atlantic voyages}

During TA1 and TA2, ballast tanks showed a significant (TA1, $\mathrm{p}=0.005$; TA2, $\mathrm{p}=0.05$ ) decrease in bacterial abundances between the beginning and end of the voyages (Fig. 4C). For both voyages, bacterial abundance at the end of the voyage was not significantly different among the 4 tanks (Table 1).

For TA1, bacterial growth rates were $-0.09 \mathrm{~d}^{-1}$ and $-0.05 \mathrm{~d}^{-1}$ for MOE1 and MOE2 tanks, respectively; that is, showing net mortality throughout the voyage (Fig. 4C, Table 2). For TA2, the average rates of bacterial growth and losses in the MOE1 and MOE2 tanks were computed for the 2 growth phases (Fig. 4D, Table 2 ). In the MOE1 tanks, a net mortality of $-0.17 \mathrm{~d}^{-1}$ was recorded between Days 1 and 4; thereafter, abundances increased at an average growth rate of $0.04 \mathrm{~d}^{-1}$ (Fig. 4D, Table 2). For MOE2 tanks 1 and 2, net mortality was observed between Days 1 and 4 at $-0.10 \mathrm{~d}^{-1}$ and $-0.16 \mathrm{~d}^{-1}$, respectively; thereafter, net growth was $0.08 \mathrm{~d}^{-1}$ and $0.13 \mathrm{~d}^{-1}$, respectively (Fig. 4D, Table 2).

The bacterial cell volumes were significantly $(p<$ 0.05) higher after MOE than before only for the MOE2 tanks during TA1 and the MOE1 tanks during TA2 (Tables $1 \& 3)$. In addition, there was a significant $(p=$ $0.007)$ increase in the percent of rod-shaped cells before MOE compared with after MOE during TA1 (MOE2 tanks only; Tables 1 \& 3). For TA2, bacterial abundance in source port waters was significantly $(\mathrm{p}=$ 0.02) higher than in receiving port waters (Table 1).

\section{Relationship with environmental parameters}

For each voyage in the different ocean basins, and for all ballast tanks, the bivariate relationship between concurrently measured ballast water bacterial abundances and temperature (Fig. 5A,B) and dissolved oxygen concentrations (Fig. 5C,D) was significant ( $p<$ 0.001), although with opposite signs. The regression equations and statistics are presented in Table 4 . When

Table 3. Bacterial cell volumes and percent rod-shaped cells (mean $\pm \mathrm{SD}$ ) in ballast tanks during trans-Pacific (TP) and transAtlantic (TA) voyages. For TP voyages, data is shown for tanks that underwent mid-ocean exchange (MOE) and those that did not (control); for TA voyages, data is for tanks that underwent exchange earlier (MOE1) and later (MOE2). Values are the mean of all cell volumes during the periods before and after MOE. For the TP control tanks, where there was no exchange, the time periods 'before' and 'after exchange' are the same as for the corresponding MOE tanks. 1-way ANOVA was used to determine differences between mean cell volumes and percent rods before and after exchange; values with different superscript letters within a row are significantly different at $\mathrm{p} \leq 0.05$

\begin{tabular}{|c|c|c|c|c|c|c|c|}
\hline \multirow{2}{*}{ Voyage } & \multirow{2}{*}{$\begin{array}{l}\text { Ballast tank } \\
\text { treatment } \\
\text { and number }\end{array}$} & \multicolumn{3}{|c|}{$\longrightarrow$ Before MOE } & \multirow{2}{*}{$\overline{\text { Days }}$} & - After MOE & \multirow{2}{*}{$\begin{array}{l}\% \text { rod-shaped } \\
\text { cells }\end{array}$} \\
\hline & & Days & $\begin{array}{c}\text { Mean cell } \\
\text { volume }\left(\mu \mathrm{m}^{3}\right)\end{array}$ & $\begin{array}{l}\% \text { rod-shaped } \\
\text { cells }\end{array}$ & & $\begin{array}{c}\text { Mean cell } \\
\text { volume }\left(\mu \mathrm{m}^{3}\right)\end{array}$ & \\
\hline \multirow[t]{4}{*}{ TP1 } & Control tank 1 & $0-13$ & 0.0525 & $18.88 \pm 0.45$ & \multirow[t]{4}{*}{$14-22$} & 0.0539 & $17.73 \pm 0.48$ \\
\hline & Control tank 2 & & 0.0520 & $16.68 \pm 0.41$ & & 0.0578 & $16.48 \pm 0.46$ \\
\hline & MOE tank 1 & & 0.0530 & $19.17 \pm 0.47$ & & 0.0519 & $17.05 \pm 0.43$ \\
\hline & MOE tank 2 & & 0.0601 & $17.63 \pm 0.42$ & & 0.0639 & $14.88 \pm 0.44$ \\
\hline \multirow[t]{4}{*}{ TP2 } & Control tank 1 & $0-14$ & 0.0587 & $19.73 \pm 0.42$ & \multirow[t]{4}{*}{$15-24$} & 0.0542 & $21.90 \pm 0.46$ \\
\hline & Control tank 2 & & 0.0535 & $14.62 \pm 0.39$ & & 0.0484 & $16.67 \pm 0.43$ \\
\hline & MOE tank 1 & & 0.0479 & $17.44 \pm 0.39$ & & 0.0526 & $20.07 \pm 0.41$ \\
\hline & MOE tank 2 & & 0.0550 & $17.37 \pm 0.41$ & & 0.0536 & $17.89 \pm 0.41$ \\
\hline \multirow[t]{4}{*}{ TA1 } & MOE1 tank 1 & $0-2$ & 0.0453 & $8.53 \pm 0.36$ & \multirow[t]{2}{*}{$3-9$} & 0.0601 & $11.22 \pm 0.41$ \\
\hline & MOE1 tank 2 & \multirow{3}{*}{$0-6$} & 0.0527 & $11.11 \pm 0.39$ & & 0.0585 & $10.37 \pm 0.40$ \\
\hline & MOE2 tank 1 & & $0.0498^{\mathrm{a}}$ & $8.06 \pm 0.37^{\mathrm{a}}$ & \multirow[t]{2}{*}{$7-9$} & $0.0670^{\mathrm{b}}$ & $12.83 \pm 0.38^{b}$ \\
\hline & MOE2 tank 2 & & $0.0484^{\mathrm{a}}$ & $8.23 \pm 0.36^{\mathrm{a}}$ & & $0.0619^{b}$ & $12.10 \pm 0.37^{b}$ \\
\hline \multirow[t]{4}{*}{ TA2 } & MOE1 tank 1 & $1-3$ & $0.0465^{\mathrm{a}}$ & $12.05 \pm 0.40$ & \multirow[t]{2}{*}{$4-8$} & $0.0545^{\mathrm{b}}$ & $10.02 \pm 0.40$ \\
\hline & MOE1 tank 2 & \multirow{3}{*}{$1-4$} & $0.0452^{\mathrm{a}}$ & $9.39 \pm 0.39$ & & $0.0565^{\mathrm{b}}$ & $11.41 \pm 0.40$ \\
\hline & MOE2 tank 1 & & 0.0589 & $11.30 \pm 0.43$ & \multirow[t]{2}{*}{$5-8$} & 0.0553 & $9.77 \pm 0.39$ \\
\hline & MOE2 tank 2 & & 0.0481 & $9.46 \pm 0.38$ & & 0.0581 & $10.21 \pm 0.39$ \\
\hline
\end{tabular}



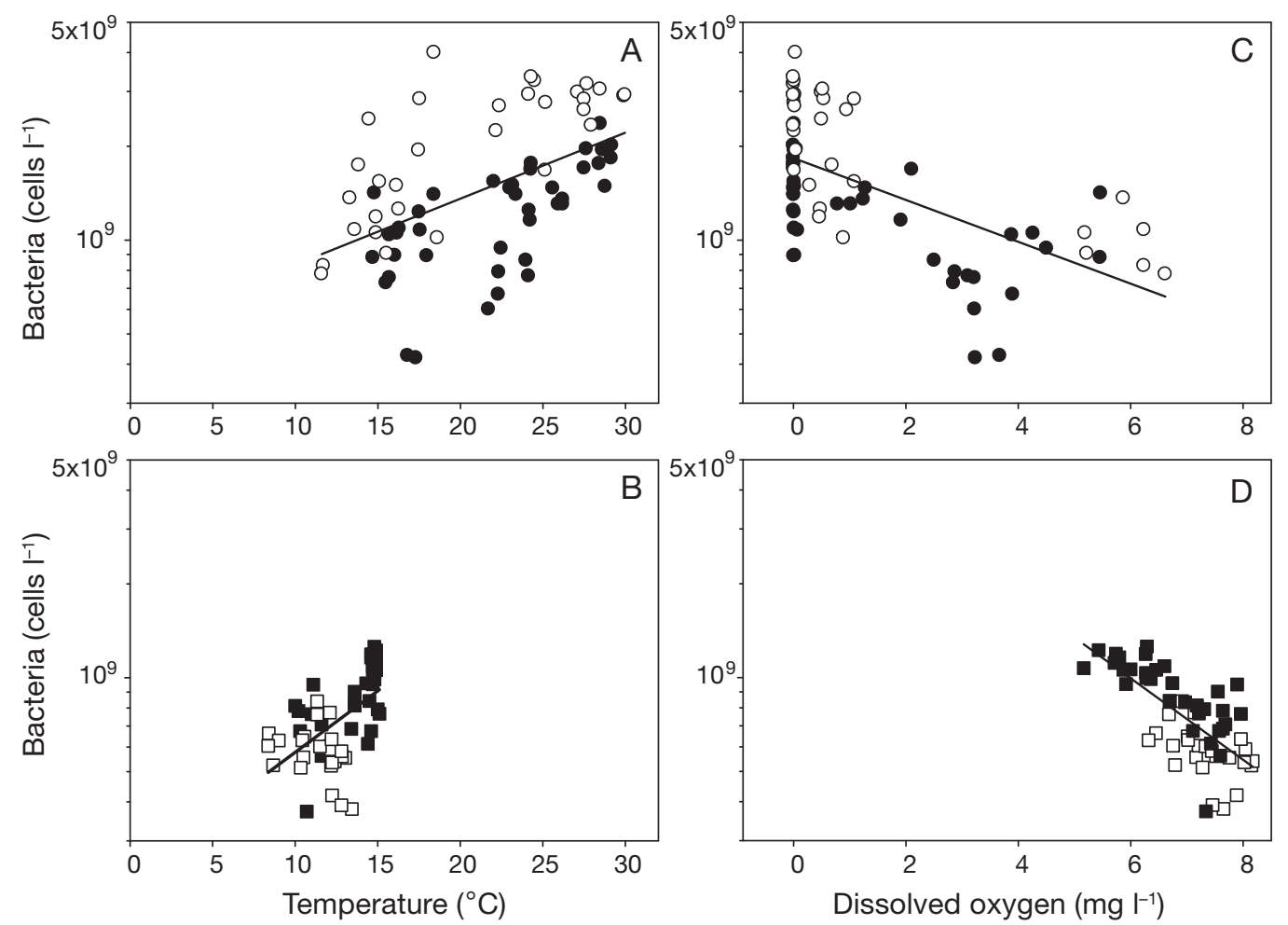

Fig. 5. Regression relationships between $(\mathrm{A}, \mathrm{B})$ bacterial abundance and temperature and $(\mathrm{C}, \mathrm{D})$ bacterial abundance and dissolved oxygen concentrations for $(A, C)$ trans-Pacific voyages TP1 $(\bullet)$ and TP2 $(O)$ and $(B, D)$ trans-Atlantic 1 voyages TA1

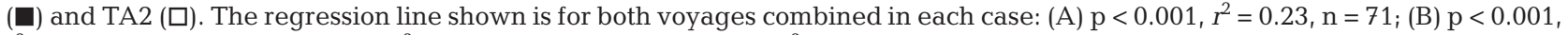
$r^{2}=0.36, \mathrm{n}=57$; (C) $\mathrm{p}<0.001, r^{2}=0.29, \mathrm{n}=71$; (D) $\mathrm{p}<0.001, r^{2}=0.56, \mathrm{n}=57$. See Table 4 for details of regression equations and statistics

bacterial abundance was predicted from multivariate regressions that include both temperature and dissolved oxygen concentrations, the explained variance was on average $33 \%$ greater than from bivariate predictive models (Table 4). The inclusion of other variables, such as percent rods and cell volume, did not increase the explained variance of the model's prediction of bacterial abundance.

When bacterial abundance, temperature, and dissolved oxygen data for the 4 voyages (i.e. both oceanic basins) were combined ( $\mathrm{n}=128$ ), there was a significant $(\mathrm{p}<0.001)$ relationship between bacterial abundance and temperature and between abundance and dissolved oxygen (Fig. 6, Table 4). When both variables were combined in a multiple regression the explained variance increased $\left(\operatorname{adj}-r^{2}=0.55 ; \mathrm{p}<0.001\right)$ (Table 4).

\section{Cellular respiration}

During TP1, bacterial respiration was significantly ( $p<0.001$ ) higher both in the control ballast tanks 1 and 2 (21.3 and $29.2 \mu \mathrm{g} \mathrm{Cl}^{-1} \mathrm{~d}^{-1}$, respectively) and MOE bal-

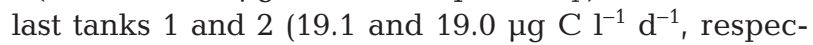

tively) ballast tanks, compared with values for TA2 MOE1 tanks 1 and 2 (0.58 and $0.09 \mu \mathrm{g} \mathrm{Cl}^{-1} \mathrm{~d}^{-1}$, respectively), and MOE2 tanks 1 and 2 (0.67 and $1.0 \mu \mathrm{g} \mathrm{C} \mathrm{l^{-1 }}$ $\mathrm{d}^{-1}$, respectively).

\section{DISCUSSION}

The dynamics of bacteria in natural waters have been well studied for several decades (Azam et al. 1983, Kirchman 2000 and references cited therein, Azam \& Malfatti 2007, Karl 2007, Pomeroy et al. 2007). Although the abundances of heterotrophic bacteria in ballast water at the deballasting locations has been reasonably well studied (Ruiz et al. 2000, Drake et al. 2002, 2007, Joachimsthal et al. 2004, Mimura et al. 2005, Burkholder et al. 2007, David et al. 2007, QuilezBadia et al. 2007, Ma et al. 2009, Sun et al. 2010), very little is known about bacterial processes in the ballast tank environment while ships are in transit. Since bacterial processes are controlled by both the physicochemical properties (i.e. temperature, dissolved nutrients, and gases) within the ballast tank water and sources of mortality (i.e. grazing pressure and viral 
Table 4. Bivariate and multiple regression equations for relationships between bacterial abundance (BA) and temperature ( $T$ ), BA and dissolved oxygen (DO), and BAand both $T$ and DO in ballast tanks during trans-Pacific (TP) and trans-Atlantic (TA) voyages. Equations are given for each voyage, each ocean basin combined, and the 4 voyages combined

\begin{tabular}{|c|c|c|c|c|c|}
\hline Voyage & Equation & $\mathrm{n}$ & $F$ & $\mathrm{p}$-value & $r^{2}$ \\
\hline \multicolumn{6}{|c|}{ Relationship with temperature } \\
\hline TP1 & $\mathrm{BA}=-2.23 \times 10^{8}+0.665 \times 10^{8} \mathrm{~T}$ & 40 & 33.36 & $<0.001$ & 0.47 \\
\hline TP2 & $\mathrm{BA}=-0.705 \times 10^{8}+1.09 \times 10^{8} \mathrm{~T}$ & 31 & 32.37 & $<0.001$ & 0.53 \\
\hline TP1 and TP2 & $\mathrm{BA}=0.394 \times 10^{8}+0.751 \times 10^{8} \mathrm{~T}$ & 71 & 21.83 & $<0.001$ & 0.24 \\
\hline TA1 & $\mathrm{BA}=-1.15 \times 10^{8}+0.750 \times 10^{8} \mathrm{~T}$ & 33 & 17.57 & $<0.001$ & 0.36 \\
\hline TA2 & $\mathrm{BA}=8.27 \times 10^{8}-0.212 \times 10^{8} \mathrm{~T}$ & 24 & 2.07 & 0.165 & 0.09 \\
\hline TA1 and TA2 & $\mathrm{BA}=-1.61 \times 10^{8}+0.736 \times 10^{8} \mathrm{~T}$ & 57 & 32.64 & $<0.001$ & 0.37 \\
\hline All voyages & $\mathrm{BA}=-2.86 \times 10^{8}+0.881 \times 10^{8} \mathrm{~T}$ & 128 & 117.88 & $<0.001$ & 0.48 \\
\hline \multicolumn{6}{|c|}{ Relationship with dissolved oxygen } \\
\hline TP1 & $\mathrm{BA}=1.50 \times 10^{9}-1.59 \times 10^{8} \mathrm{DO}$ & 40 & 23.72 & $<0.001$ & 0.38 \\
\hline TP2 & $\mathrm{BA}=2.55 \times 10^{9}-2.70 \times 10^{8} \mathrm{DO}$ & 31 & 24.41 & $<0.001$ & 0.46 \\
\hline TP1 and TP2 & $\mathrm{BA}=1.99 \times 10^{9}-2.27 \times 10^{8} \mathrm{DO}$ & 71 & 30.11 & $<0.001$ & 0.30 \\
\hline TA1 & $\mathrm{BA}=2.34 \times 10^{9}-2.12 \times 10^{8} \mathrm{DO}$ & 33 & 47.86 & $<0.001$ & 0.61 \\
\hline TA2 & $\mathrm{BA}=1.32 \times 10^{9}-1.00 \times 10^{8} \mathrm{DO}$ & 24 & 6.98 & 0.015 & 0.24 \\
\hline TA1 and TA2 & $\mathrm{BA}=2.45 \times 10^{9}-2.39 \times 10^{8} \mathrm{DO}$ & 57 & 70.70 & $<0.001$ & 0.56 \\
\hline All voyages & $\mathrm{BA}=1.95 \times 10^{9}-1.76 \times 10^{8} \mathrm{DO}$ & 128 & 140.10 & $<0.001$ & 0.53 \\
\hline \multicolumn{5}{|c|}{ Relationship with temperature and dissolved oxygen } & Adj- $-r^{2}$ \\
\hline TP1 & $\mathrm{BA}=3.26 \times 10^{8}+0.483 \times 10^{8} \mathrm{~T}-0.94 \times 10^{8} \mathrm{DO}$ & 40 & 23.98 & $<0.001$ & 0.54 \\
\hline TP2 & $\mathrm{BA}=8.35 \times 10^{8}+0.747 \times 10^{8} T-1.46 \times 10^{8} \mathrm{DO}$ & 31 & 21.83 & $<0.001$ & 0.58 \\
\hline TP1 and TP2 & $\mathrm{BA}=1.03 \times 10^{9}+0.403 \times 10^{8} T-1.66 \times 10^{8} \mathrm{DO}$ & 71 & 18.38 & $<0.001$ & 0.33 \\
\hline TA1 & $\mathrm{BA}=2.00 \times 10^{9}+0.139 \times 10^{8} T-1.90 \times 10^{8} \mathrm{DO}$ & 33 & 23.79 & $<0.001$ & 0.59 \\
\hline TA2 & $\mathrm{BA}=1.38 \times 10^{9}+0.143 \times 10^{8} \mathrm{~T}-1.31 \times 10^{8} \mathrm{DO}$ & 24 & 3.63 & 0.044 & 0.19 \\
\hline TA1 and TA2 & $\mathrm{BA}=1.56 \times 10^{9}+0.438 \times 10^{8} T-1.92 \times 10^{8} \mathrm{DO}$ & 57 & 55.26 & $<0.001$ & 0.66 \\
\hline All voyages & $\mathrm{BA}=1.02 \times 10^{9}+0.392 \times 10^{8} T-1.15 \times 10^{8} \mathrm{DO}$ & 128 & 79.07 & $<0.001$ & 0.55 \\
\hline
\end{tabular}

lysis; Thingstad 2000, Cuevas \& Morales 2006, Pradeep Ram \& Sime-Ngando 2008), the abundance at deballasting will reflect an integration of these factors prior to the arrival of a ship in port.

Burkholder et al. (2007) and Sun et al. (2010) reported no significant relationships between the endof-voyage bacterial abundance and concurrently measured environmental parameters (temperature, salinity, dissolved oxygen concentrations and $\mathrm{pH}$ ). The absence of relationships is not surprising. The ballast tank environment is physically and chemically dynamic and, since bacterial abundance depends on nutrient availability, physical conditions and mortality, the population size at the end of the voyage reflects a complex interplay of factors that change during the voyage. Hence, correlations and predictive relationships will be more robust when based on an understanding of the factors that influence bacterial abundance (and dynamics) in ballast water during, and not just at the end of, the voyage. Drake et al. (2002) reported changes in bacterial abundance during a $19 \mathrm{~d}$ TA voyage onboard a bulk carrier and determined bacterial abundances to be lower at the end of a voyage compared with the beginning. Mimura et al. (2005) reported that MOE did not reduce the number of viable cells (as determined by the number of colony forming units) during 6 voyages from Japan to Qatar. Neither study related microbial metrics to the environmental parameters of the ballast water.

During a preliminary study, based upon TP1 only, Seiden et al. (2010) related changes in ballast water bacterial abundance to concurrently measured physical conditions during a single TP voyage and showed a significant positive relationship between bacterial abundance in ballast water and temperature and a significant inverse relationship with dissolved oxygen concentrations. Although these observations were based on a very limited data set, the relationship with temperature is consistent with other studies of bacteria in coastal and estuarine environments (White et al. 1991, Hoch \& Kirchman 1993, Granéli et al. 2004). Similar relationships between bacterial abundance and dissolved oxygen concentrations have not previously been reported in natural systems or ballast tanks. In our study, the broad geographic (2 ocean basins) and temporal (summer through late fall) scope enables us to assess whether the relationships initially reported by Seiden et al. (2010) represent general patterns. We show in Fig. 6 that despite sampling in the different ocean basins, with distinct source waters during dis- 

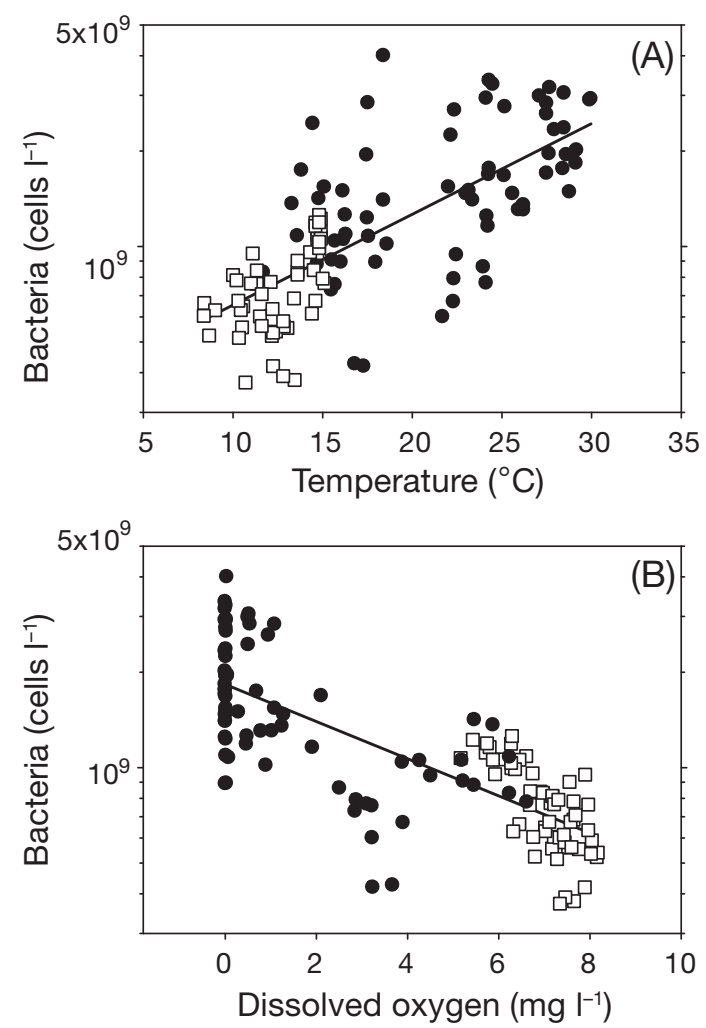

Fig. 6. Relationship between (A) temperature and bacterial abundance and (B) bacterial abundance and dissolved oxygen concentrations for trans-Pacific voyages TP1 and TP2 combined $(\bullet)$ and trans-Atlantic voyages TA1 and TA2 combined ( $\square$ ). Regression statistics shown are for all voyages: (A) $\mathrm{p}<0.001, r^{2}=0.48, \mathrm{n}=128$; (B) $\mathrm{p}<0.001, r^{2}=0.53, \mathrm{n}=128$. See Table 4 for detailed regression equations and statistics

tinct seasons, and with different environmental characteristics in the ballast tanks, the relationships between bacterial abundance and ballast water temperature and dissolved oxygen concentrations are similar. This robust relationship permits the development of a predictive model of bacterial abundances from physical variables. We show (Table 4) that by using both temperature and dissolved oxygen concentrations as predictor variables, the prediction of bacterial abundance is stronger than when each variable is separately considered.

\section{Bacterial dynamics and environmental conditions}

The biomass, abundance, and biodiversity of other ballast water plankton, such as zooplankton and phytoplankton generally decrease during transit. The time dependent patterns are generally complex and taxon specific (Gollasch et al. 2000a,b, Olenin et al. 2000, Wonham et al. 2001, McCollin et al. 2007, 2008, Taylor et al. 2007, Klein et al. 2009). In the present study, there were different patterns of bacterial dynamics for the $2 \mathrm{TP}$ voyages that may reflect the different source of the ballast waters. Moreover, we observed different patterns of bacterial dynamics during the Pacific and Atlantic voyages. The differences in dynamics between the 2 ocean basins could be due to several reasons. (1) The shipping routes are different (Atlantic vs. Pacific) with distinct temperature regimes that will affect growth patterns. During the TP voyages for example, the ballast tank water was exposed to higher and more variable temperatures. During all voyages, there was an overall decline in temperature and the trends in all of the tanks within individual voyages were generally the same. The temperature of the ballast tanks of all voyages paralleled (at times with a small time lag) the ambient ocean water temperatures (Fig. 2A-D). (2) The duration of the voyage will vary depending on the route, and this will have consequences for the number of bacteria deballasted, i.e. the longer the voyage, the lower the abundance of bacteria in the ballast water. For example, during TP1, the bacterial abundances were significantly higher 7 to $10 \mathrm{~d}$ after the start of the voyage than at the end, and if deballasting took place before Day 10 rather than on Day 22, the propagule pressure would have been 1.8and 3.7-fold higher from control and MOE tanks, respectively. (3) The origin of the source water differed and thus contains different bacterial assemblages as well as grazer and viral components, which will affect bacterial mortality. (4) There will be different environmental characteristics, such as initial dissolved oxygen concentrations. In the present study, there were different patterns in dissolved oxygen concentrations during the Pacific and Atlantic voyages with lower (near anoxic) dissolved oxygen concentrations during the TP voyages (Fig. 3). The latter is consistent with Drake et al. (2002) who also reported only a small decline in dissolved oxygen concentrations during a TA voyage.

The differences in the dissolved oxygen patterns between the TP and TA voyages may be due to a number of factors including ballast tank configuration and size, sea state, ambient temperature, source water composition and characteristics. The relatively small size of the ballast tanks $\left(445 \mathrm{~m}^{3}\right)$ on the MV 'Skaugran' (vs. 5833-11 $648 \mathrm{~m}^{3}$ on the 'Eva N'), along with the different source of the ballast water, and the higher temperatures during the TP voyages may have combined to enhance the rate of oxygen depletion. In the smaller ballast tanks, an overall higher biological oxygen demand from the source water combined with a 2 to 3 times longer voyage duration during the TP than TA voyages contributed to the rapid decline in dissolved oxygen in the ballast tanks (Fig. 3). Moreover, the higher temperatures would increase bacterial growth, production and respiration rates, and thus consump- 
tion of oxygen. Bacterial respiration in the ballast tanks, which was likely underestimated since the rates of bacterial production were determined from net growth rates (growth rates minus grazing mortality), was significantly higher in ballast tanks during the TP voyage compared with the TA voyage. This explains, in part, the oxygen depletion patterns observed in these voyages.

During the TA voyages, bacterial cell volume was significantly larger after exchange for 2 sets of tanks (Tables 1 \& 3). Since cell size may be both an indicator of the nutrient status of bacteria (small-size bacterial cells are typically considered to be nutrient limited; Ducklow \& Carlson 1992) and grazing activity (protists tend to select large cells and shift the size distribution to small-size bacteria; Šimek et al. 2001), the observed pattern suggests that ballast water bacteria were likely both nutrient-limited and being grazed more actively before MOE compared with afterwards.

\section{Model development and validation}

Although bacterial growth dynamics in the ballast water differed during the voyages and between ocean basins, the general relationships with environmental parameters were the same. This clearly demonstrates the fundamental nature of the relationship and its potential application in understanding and predicting the propagule pressure of bacteria in ballast water. It also shows that the shipping route can potentially influence bacterial dynamics and bacterial abundances in ballast water and ultimately the propagule pressure at the deballasting location.

The significant relationship between bacterial abundance and temperature and dissolved oxygen can be used to predict ballast water bacterial abundance. We tested the validity of the model by using one data set to develop the predictive model and a separate and independent data set to validate the model. The regression model based on the starboard-side ballast tanks is

$$
\begin{gathered}
\mathrm{BA}_{\text {Starboard }}=1.04 \times 10^{9}+0.375 \times 10^{8} T-1.16 \times 10^{8} \mathrm{DO} \\
\left(F=30.45 ; \mathrm{p}<0.001 ; \mathrm{n}=64 ; \text { adj }-r^{2}=0.48\right)
\end{gathered}
$$

and the regression model based on port-side ballast tanks is

$$
\begin{gathered}
\mathrm{BA}_{\text {Port }}=9.88 \times 10^{8}+0.418 \times 10^{8} T-1.12 \times 10^{8} \mathrm{DO} \\
\left(F=51.20 ; \mathrm{p}<0.001 ; \mathrm{n}=64 ; \text { adj }-r^{2}=0.61\right)
\end{gathered}
$$

where $T$ is temperature $\left({ }^{\circ} \mathrm{C}\right)$ and DO is dissolved oxygen ( $\left.\mathrm{mg} \mathrm{O}_{2} \mathrm{l}^{-1}\right)$.

Using the starboard-side ballast tank model, we predicted port-side ballast water bacterial abundance using the observed port-side ballast tank temperature and dissolved oxygen concentrations. Using the port- side ballast tank model, we predicted starboard-side ballast water bacterial abundance using the observed starboard-side temperatures and dissolved oxygen concentrations. We then compared the predicted values of each data set to the observed values of each data set and tested this relationship using Reduced Major Axis Model 2 regression (Fig. 7). The slope of the portside RMA regression of observed vs. predicted bacterial abundance is $0.824(\mathrm{p}=0.01 ; 95 \% \mathrm{CI}=$ $0.680-1.010$ ) and the slope of the starboard-side observed vs. predicted bacterial abundance is $1.238(\mathrm{p}=$ 0.01 ; $95 \%$ CI $=0.975-1.635)$, neither of these slopes were significantly different from 1.00. When we combine the predicted and observed bacterial abundances for all port- and starboard-side tanks in a single RMA regression, the slope is closer to 1.00 (slope $=1.106 ; \mathrm{p}=$ $0.01 ; 95 \% \mathrm{CI}=0.934-1.332$ ). The results demonstrate the potential for this model to be developed into a management tool to predict bacterial propagule pressure from environmental parameters of the ballast tank water before deballasting. This is potentially important since there are no current treatment options that safely and in a cost effective manner eliminate the entire bacterial population from ballast water (Dobbs \& Rogerson 2005). The effect of dissolved oxygen concentrations and temperatures on bacterial abundances may be either direct or indirect, and may be mediated (at least in part) by changes in the sources and magnitude of viral- or grazer-mediated mortality.

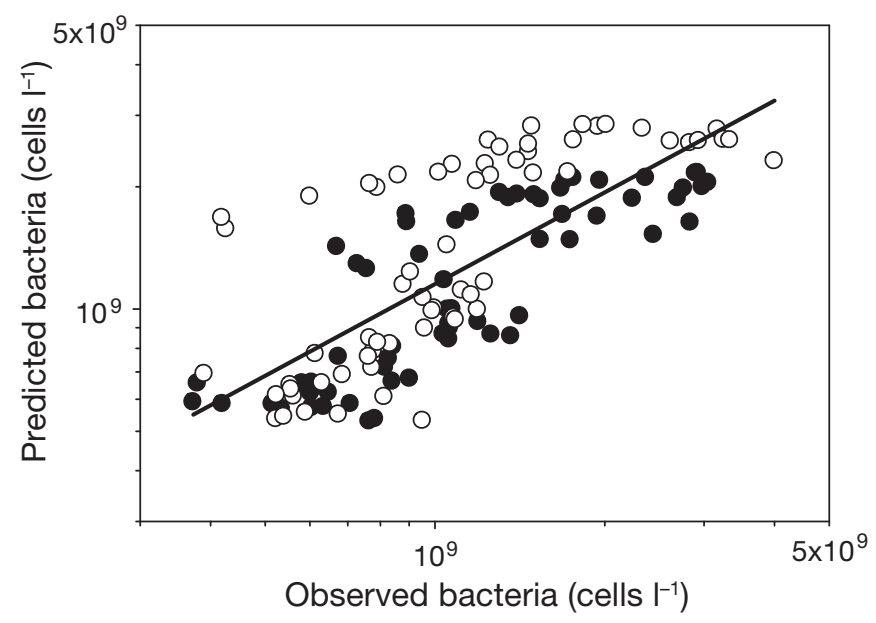

Fig. 7. Model 2 (Reduced Major Axis) regression relationships between predicted and observed bacterial abundance of all voyages for port-side $(\bullet)$ and starboard-side $(O)$ ballast tanks. Port-side ballast tank bacterial abundances were predicted from a model based on starboard-side ballast tank parameters and vice versa. The slopes of all 3 Model 2 regressions (portside abundances, starboard-side abundances, and both combined) were not significantly different from 1.00 (based on $95 \%$ confidence intervals; see text for details). The displayed regression line is for all abundances 


\section{MOE efficacy}

The effect of MOE on bacterial abundances in ballast water is variable (Drake et al. 2002, Mimura et al. 2005, Sun et al. 2010, Quilez-Badia et al. 2007). During a 2-yr study of ships arriving at the Port of Vancouver, British Columbia, Sun et al. (2010) reported that MOE tanks had significantly lower bacterial abundances compared with unexchanged tanks, and abundances in tanks were lower than in receiving port waters. Although Quilez-Badia et al. (2007) reported that bacterial abundances were generally lower in the ballast water of MOE tanks compared with unexchanged tanks during 22 ocean voyages, in $4 \%$ of the tanks sampled (both MOE and unexchanged tanks) they found end-of-voyage bacterial abundances to be higher at the end than at the beginning. In contrast, Drake et al. (2002) reported no significant difference between MOE and unexchanged ballast tanks on the last voyage day, and Mimura et al. (2005) reported inconsistent results. In the present study, during TP1, there was a significant increase in bacterial abundances during the first 7 to $10 \mathrm{~d}$ of the voyage in the control and MOE tanks. Although MOE reduced bacterial abundances, the decline began before MOE and, therefore, the reduction was only in part due to the dilution of ballast water with oceanic waters. In addition, out of all voyages reported, only the MOE1 tanks during TA1 showed a significant reduction in bacterial abundances immediately after MOE. This is not particularly surprising considering open-ocean water bacterial concentrations range between 5 and $10 \times 10^{8}$ cells $\mathrm{l}^{-1}$ (Sherr \& Sherr 2000, Whitman et al. 1998).

In the present study, the end-of-voyage bacterial abundances in the control and MOE ballast tanks were not significantly different (Table 1). The results of the present and other studies show that bacterial propagule pressure in ballast water can vary and is dependent on a variety of factors, including the conditions in the ballast tank and on the duration of the voyage (Sun et al. 2010), and that MOE does not consistently reduce bacterial abundances. The variability in the reported effect of MOE on reducing bacterial numbers in ballast water, and the relationship between bacterial abundances in receiving port waters and ballast water, demonstrates the fundamental complexity in ballast tank microbial dynamics, and this confounds our developing a simple relationship to predict propagule pressure. Such models could facilitate the development of methods to control ballast water bacteria populations.

This conclusion highlights the importance of understanding the physical and biological controls on bacteria during transit. The economic and ecological impact of ballast-water-borne bacteria is a function of both the total number of bacteria introduced and the composition of the bacterial assemblage. Because the composition of naturally occurring bacterial communities displays a marked biogeography (Hughes Martiny et al. 2006, Ramette \& Tiedje 2007), with distinct estuarine, coastal, and oceanic populations (Rappé et al. 2000, Hewson \& Fuhrman 2004, Malmstrom et al. 2007), MOE could affect the composition of ballast tank bacterial assemblages. Coastal waters, where ballast water is taken onboard, are generally affected by landoriginated pollution, such as sewage effluent and agricultural run-off; hence, MOE could be especially important in reducing the introduction of pathogenic bacteria (EPA 2006). For example, Vibrio cholera (e.g. strains O1 and O139) and Escherichia coli have been found in ballast water (McCarthy \& Khambaty 1994, Ruiz et al. 2000, Joachimsthal et al. 2004, Burkholder et al. 2007). Ma et al. (2009) found Xiamen (China) port water to contain pathogenic bacterial strains, demonstrating polluted coastal seawater and highlighting the risk of potential transference in ballast water. Hence, even if MOE does not significantly reduce bacterial propagule pressure in ballast water, it may be effective in reducing the introduction of pathogenic bacteria.

Despite the different bacterial dynamics among the 4 voyages, the following conclusions can be drawn from this study: (1) The relationship between bacterial abundance and temperature and dissolved oxygen concentrations is consistent. When tested, the model was able to predict ballast water bacterial abundance using temperature and dissolved oxygen, and this has the potential to be a useful management tool. By using remotely sensed (i.e. satellite derived) sea surface temperatures to choose a low temperature ocean location for MOE, bacterial propagule pressure may be effectively reduced at deballasting sites. (2) MOE does not significantly reduce bacterial numbers; there were no differences between MOE tanks and unexchanged tanks at the end of voyages and ballast water had significantly higher abundances than receiving port waters. It is clearly necessary to examine changes in community structure to fully determine the efficacy of MOE and its role in reducing the introduction of pathogenic bacteria. (3) The general pattern of decline in bacterial abundance reported here (and also reported by Drake et al. 2002) suggests that the duration of the voyage plays a critical role in determining the bacterial propagule pressure.

Acknowledgements. This study was carried out as partial fulfillment of an MSc. degree (JMS) in the Graduate Environmental Science Programme at Memorial University of Newfoundland and Labrador. The work was funded and supported by the Canadian Aquatic Invasive Species Network (CAISN), a grant from the Natural Sciences and Engineering Research Council of Canada (NSERC) to RBR, and an 
NSERC Alexander Graham Bell Canada Graduate Scholarship and School of Graduate Studies, Memorial University, Scholarship to J.M.S. Special thanks to Donald Humphrey, Jonas Leichsenring, Andrea Weise, and Beth Piercey for collecting water samples for the voyages, to Rebecca Mouland for her invaluable laboratory assistance in determining cell volumes for the TA voyages, to Matthew W. Walsh for his help in making the maps indicating the shipping route, to Tiago Hori for his help with the program computing Model 2 regressions, and to the captain and crews of the MV 'Skaugran' and MV 'Eva N' for allowing their vessels to be used in the study.

\section{LITERATURE CITED}

Azam F, Malfatti F (2007) Microbial structuring of marine ecosystems. Natl Rev 5:782-791

Azam F, Fenchel T, Field JG, Gray JS, Meyer-Reil LA, Thingstad F (1983) The ecological role of water-column microbes in the sea. Mar Ecol Prog Ser 10:257-263

Burkholder JM, Hallegraeff GM, Melia G, Cohen A and others (2007) Phytoplankton and bacterial assemblages in ballast water of U.S. Military ships as a function of port of origin, voyage time, and ocean exchange practices. Harmful Algae 6:486-518

Carlton JT (1999) The scale and ecological consequences of biological invasions in the world's oceans. In: Sandlund OT, Schei PJ, Viken A (eds) Invasive species and biodiversity management. Kluwer Academic, Dordrecht, p 195-212

> Cuevas LA, Morales CE (2006) Nanoheterotroph grazing on bacteria and cyanobacteria in oxic and suboxic waters in coastal upwelling areas off northern Chile. J Plankton Res 28:385-397

David M, Gollasch S, Cabrini M, Perkovič M, Bošnjak D, Virgilio D (2007) Results from the first ballast water sampling study in the Mediterranean Sea — the Port of Koper study. Mar Pollut Bull 54:53-65

DFO (Fisheries and Oceans Canada) (2007) Aquatic invasive species. www.dfo-mpo.gc.ca/science/enviro/ais-eae/indexeng.htm

> Dobbs FC, Rogerson A (2005) Ridding ships' ballast water of microorganisms. Environ Sci Technol 39:259A-264A

> Drake LA, Ruiz GM, Galil BS, Mullady TL, Friedmann DO, Dobbs FC (2002) Microbial ecology of ballast water during a transoceanic voyage and the effects of open-ocean exchange. Mar Ecol Prog Ser 233:13-20

Drake LA, Doblin MA, Dobbs FC (2007) Potential microbial bioinvasions via ships' ballast water, sediment, and biofilm. Mar Pollut Bull 55:333-341

Ducklow HW, Carlson CA (1992) Oceanic bacterial production. In: Marshall KC (ed) Advances in microbial ecology. Plenum Press, New York, NY, p 113-118

EPA (Environment Protection Authority) (2006) Water quality. www.epa.sa.gov.au/water_what.html

Gollasch S, Lenz J, Dammer M, Andres HG (2000a) Survival of tropical ballast water organisms during a cruise from the Indian Ocean to the North Sea. J Plankton Res 22: 923-937

Gollasch S, Rosenthal H, Botnen $\mathrm{H}$, Hamer $\mathrm{J}$ and others (2000b) Fluctuations of zooplankton taxa in ballast water during short-term and long-term ocean-going voyages. Int Rev Hydrobiol 85:597-608

Granéli W, Carlsson P, Bertilsson S (2004) Bacterial abundance, production and organic carbon limitation in the Southern Ocean $\left(39-62^{\circ} \mathrm{S}, 4-14^{\circ} \mathrm{E}\right)$ during the austral summer 1997/1998. Deep Sea Res II 51:2569-2582

Gregg MD, Hallegraeff GM (2007) Efficacy of three commer- cially available ballast water biocides against vegetative microalgae, dinoflagellate cysts and bacteria. Harmful Algae 6:567-584

- Hallegraeff GM (1998) Transport of toxic dinoflagellates via ships' ballast water: bioeconomic risk assessment and efficacy of possible ballast water management strategies. Mar Ecol Prog Ser 168:297-309

Hebert PDN, Muncaster BW, Mackie GL (1989) Ecological and genetic studies on Dreissena polymorpha (Pallas): a new mollusk in the Great Lakes. Can J Fish Aquatic Sci 46:1587-1591

> Hewson I, Fuhrman JA (2004) Richness and diversity of bacterioplankton species along an estuarine gradient in Moreton Bay, Australia. Appl Environ Microbiol 70: 3425-3433

Hoch MP, Kirchman DL (1993) Seasonal and inter-annual variability in bacterial production and biomass in a temperate estuary. Mar Ecol Prog Ser 98:283-295

Hughes Martiny JB, Bohannan BJM, Brown JH, Colwell RK and others (2006) Microbial biogeography: putting microorganisms on the map. Nature 4:102-112

IMO (International Marine Organization) (2008) Global ballast water management programme. http://globallast. imo.org

Joachimsthal EL, Ivanov V, Tay STL, Tay JH (2004) Bacteriological examination of ballast water in Singapore Harbour by flow cytometry with FISH. Mar Pollut Bull 49:334-343

Karl DM (2007) Microbial oceanography: paradigms, processes and promise. Natl Rev 5:759-769

Kirchman DL (ed) (2000) Microbial ecology of the oceans. Wiley-Liss, New York, NY

Klein G, MacIntosh K, Kaczmarska I, Ehrman JM (2009) Diatom survivorship in ballast water during trans-Pacific crossings. Biol Invasions 12:1031-1044

Ma Y, Xiong H, Tang S, Yang Q, Li M (2009) Comparison of the community structure of planktonic bacteria in ballast water from entry ships and local sea water in Xiamen Port. Prog Nat Sci 19:947-953

> MacIsaac HJ, Robbins TC, Lewis MA (2002) Modeling ships' ballast water as invasion threats to the Great Lakes. Can J Fish Aquat Sci 59:1245-1256

Malmstrom RR, Straza TRA, Cottrell MT, Kirchman DL (2007) Diversity, abundance, and biomass production of bacterial groups in the western Arctic Ocean. Aquat Microb Ecol 47:45-55

- McCarthy SA, Khambaty FM (1994) International dissemination of epidemic Vibrio cholera by cargo ship ballast and other nonpotable waters. Appl Environ Microbiol 60: 2597-2601

McCollin T, Shanks AM, Dunn J (2007) The efficiency of regional ballast water exchange: changes in phytoplankton abundance and diversity. Harmful Algae 6:531-546

McCollin T, Shanks AM, Dunn J (2008) Changes in zooplankton abundance and diversity after ballast water exchange in regional seas. Mar Poll Bull 56:834-844

Mimura H, Katakura R, Ishida H (2005) Changes of microbial populations in a ship's ballast water and sediments on a voyage from Japan to Qatar. Mar Pollut Bull 50:751-757

Norland S (1993) The relationship between biomass and volume of bacteria. In: Kemp PF, Sherr BF, Sherr EB, Cole JJ (eds) Handbook of methods in aquatic microbial ecology. Lewis Publishers, Boca Raton, FL, p 303-307.

Olenin S, Gollasch S, Jonušas S, Rimkut I (2000) En route investigations of plankton in ballast water on a ship's voyage from the Baltic Sea to the open Atlantic coast of Europe. Int Rev Hydrobiol 85:577-596

Pomeroy LR, Williams PJleB, Azam F, Hobbie JE (2007) The 
microbial loop. Oceanography 20:28-33

Porter KG, Feig YS (1980) The use of DAPI for identifying and counting aquatic microflora. Am Soc Limnol Oceanogr 25:943-948

Pradeep Ram AS, Sime-Ngando T (2008) Functional responses of prokaryotes and viruses to grazer effects and nutrient additions in freshwater microcosms. ISME J 2:498-509

Quilez-Badia G, Smith G, Ruiz GM (2007) Changing concentrations of bacteria in ships' ballast water during transit: are ballast tanks incubators? Rapp Comm Int Mer Medit 38:577

Ramette A, Tiedje JM (2007) Biogeography: an emerging cornerstone for understanding prokaryotic diversity, ecology and evolution. Microb Ecol 53:197-207

Rappé MS, Vergin K, Giovanni SJ (2000) Phylogenetic comparisons of a coastal bacterioplankton community with its counterparts in open ocean and freshwater systems. FEMS Microbiol Ecol 33:219-232

Rigby GR, Hallegraeff GM, Sutton C (1999) Novel ballast water heating technique offers cost effective treatment to reduce the risk of global transport of harmful marine organisms. Mar Ecol Prog Ser 191:289-293

Rilov G, Crooks JA (eds) 2009. Marine bioinvasions: conservation hazards and vehicles for ecological understanding. In: Biological invasions in marine ecosystems. Ecological studies, Vol 204. Springer-Verlag Berlin, p 3-11

Rivkin RB, Legendre L (2001) Biogenic carbon cycling in the upper ocean: effects of microbial respiration. Science 291: 2398-2400

Ruiz GM, Reid DF (2007) Current state of understanding about the effectiveness of ballast water exchange (BWE) in reducing aquatic nonindigenous species (ANS) introductions to the Great Lakes Basin and Chesapeake Bay, USA: synthesis and analysis of existing information. US Dept of Commerce, NOAA Technical Memorandum GLERL-142

Ruiz GM, Rawlings TK, Dobbs FC, Drake LA, Mullady T, Huq A, Colwell RR (2000) Global spread of microorganisms by ships. Nature 408:49-50

Seiden JM, Way CJ, Rivkin RB (2010) Microbial hitchhikers:

Editorial responsibility: Antonio Bode,

A Coruña, Spain dynamics of bacterial populations in ballast water during a trans-Pacific voyage of a bulk carrier. Aquatic Invasions 5: 13-22

Sherr E, Sherr B (2000) Marine microbes: an overview. In: Kirchman DL (ed) Microbial ecology of the oceans. WileyLiss, New York, NY, p 13-46

Šimek K, Pernthaler J, Weinbauer MG, Hornák K and others (2001) Changes in bacterial community composition and dynamics and viral mortality rates associated with enhanced flagellate grazing in a mesoeutrophic reservoir. Appl Environ Microbiol 67:2723-2733

Sun B, Mouland R, Way C, Rivkin RB (2010) Redistribution of heterotrophic prokaryotes through ballast water: a case study from the west coast of Canada. Aquatic Invasions 5: 5-11

Taylor MD, MacKenzie LM, Dodgshun TJ, Hopkins GA, de Zwart EJ, Hunt CD (2007) Trans-Pacific shipboard trials on planktonic communities as indicators of open ocean ballast water exchange. Mar Ecol Prog Ser 350:41-54

Thingstad TF (2000) Control of bacterial growth in idealized food webs. In: Kirchman DL (ed) Microbial ecology of the oceans. Wiley-Liss, New York, NY, p 229-260

Tomaru A, Kawachi M, Demura M, Fukuyo Y (2010) Denaturing gradient gel electrophoresis shows that bacterial communities change with mid-ocean ballast water exchange. Mar Pollut Bull 60:299-302

Transport Canada (2007) Ballast water management. www. tc.gc.ca/eng/marinesafety/oep-environment-ballastwatermanagement-1963.htm

White PA, Kalff J, Rasmussen JB, Gasol JM (1991) The effect of temperature and algal biomass on bacterial production and specific growth rate in freshwater and marine habitats. Microb Ecol 21:99-118

Whitman WB, Coleman DC, Wiebe WJ (1998) Prokaryotes: the unseen majority. Proc Natl Acad Sci USA 95: 6578-6583

Wonham MJ, Walton WC, Ruiz GM, Frese AM, Galil BS (2001) Going to the source: role of the invasion pathway in determining potential invaders. Mar Ecol Prog Ser 215: $1-12$

Submitted: December 27, 2010; Accepted: May 25, 2011

Proofs received from author(s): August 18, 2011 